\title{
SOME HYDRODYNAMIC PROBLEMS FOR FLOOD FORECASTING AND FLOOD CONTROL IN THE RED RIVER SYSTEM
}

\author{
NGUYEN VAN DiEP \\ Institute of Mechanics, VAST
}

\begin{abstract}
My research \& development activity in the field of environmental \& natural fluid mechanics has been started after one year's working visit, proposed by Prof. Nguyen Van Dao, at the Laboratoire National d'Hydraulique de France in Chatou, France (19791980). Until now this activity is still a most important one.

In the paper it is presented some selected scientific results in one of hydrodynamic problems for flood forecasting and flood control: developing of the 1D hydraulic model, 1D \& quasi 2D model, 1D hydraulic model for dam break flow, 2D hydraulic model, coupling of $1 \mathrm{D}$ and $2 \mathrm{D}$ hydraulic models and some theirs applications for flood forecasting and flood control in the Red River System.

This paper is dedicated to the memory of Prof. Nguyen Van Dao, with whom I had a big chance to work and to collaborate during about 30 years, to whom I would like to express my heartfelt thanks.
\end{abstract}

\section{PROF. NGUYEN VAN DAO AND MY RESEARCH AND DEVELOPMENT ACTIVITIES IN THE ENVIRONMENTAL AND NATURAL FLUID MECHANICS}

In 1977 year I have finished my thesis for obtaining the degree of Doctor of Science in the Moscow University and returned to Vietnam. At this time Prof. Nguyen Van Dao has been the General Secretary of the Vietnam Institute of Science. With his invitation and by his suggestion I have been appointed to a position of the Chief of Laboratory of Mechanics.

During my long stay in Moscow University - a palace of fundamental sciences not only in the former Soviet Union, but also in the World, I tried to learn and to find out about perspective trends in modern development of mechanics as a branch of fundamental sciences. In my understandings and conclusions, the most perspective trend in modern development of mechanics is following: mechanics needs to be originated from the technical and technological developments, from the problems of exploitation and protection of .natural resources and environment [1]. At this time, I have been interested only in two problems of mechanics: mechanical problems for oil \& gas exploitation \& transportation and aero-dynamical problems for military technique developments.

But suddenly, in 1979 Prof. Nguyen Van Dao has proposed me to take a working visit at Laboratoire National d'Hydraulique de France in Chatou, France (1979-1980). This visit has been organised by Dr. Nguyen Quoc Son and Dr. Dang Van Ky, research directors of Laboratoire de Mecanique des Solides, L'Ecole Polytechnique de Palaiseau, Paris. During one year's stay in this laboratory, I tried to learn how to apply fundamental 
problems of hydromechanics for solving practical issues in water resources management in Vietnam. From this time, the environmental \& natural mechanics became one of my most important research and development activities.

With my initiative and efforts the Institute of Mechanics became one of strongest research units working in the field of Environmental \& Natural Fluid Mechanics, and is responsible for realizing different research projects in the level of national and international programs in this field. The main of these are:

- Research Project on Salinity Intrusion Prediction Methods for Mekong River System (National Research Program on Mekong Delta Water Recourses Research, 1981-1985, Ministry of Science and Technique).

- Research Project on Litho-hydrodynamic Processes (National Marine Research Program, 1986-1990, Ministry of Science, Technology and Environment).

- Research Project on Creation of Numerical Modeling Technology for Flood Control in the Red River System (National Research Program on Flood Control for the Red River System, 1999-2000, Ministry of Agriculture and Rural Development).

- Research Project on the Scientific Bases for Flood Forecasting and Flood Control in the Red River System (National Research Program on Environmental Protection and Natural Disaster Prevention, 2001-2004, Ministry of Science and Technology) [2].

- Research Project on Decision Support System for ecosystem upgrading and flood control of a sustainable development in the Red River System (China, Vietnam), Pilot Phase (supported by the European Commission, 2001-2004) [3].

- Research Project on building regulation rules for operation of Hoa Binh, Thac Ba, Tuyen Quang and Son La reservoirs to guarantee safety to flood protection in the Red River Basin (National Research Program on Multipurpose Multiple Reservoir Operation, 2006-2007, Ministry of Agriculture and Rural Development).

In realizing these projects many scientific research results have been transferred to and used in some organizations, for example, the Central Committee for Flood and Storm Prevention, National Centre for Meteor-Hydrological Forecasting and other water resources management and planning organizations.

To dedicate to the memory of Prof. Nguyen Van Dao, in this paper there will be presented some my research activities in flood forecasting and flood control in the Red River Basin [2-9].

\section{FLOOD FORECASTING AND FLOOD CONTROL IN THE RED RIVER SYSTEM}

Red - Thai Binh River System is the second biggest river system in Vietnam, after Mekong River.

In recent years, big floods frequently happened in Vietnam, and flood disaster causes massive losses of human life and immense damages. To reduce these damages caused by floods, for short-term and long-term flood prevention and control in the Red - Thai Binh River basin followings measures are taken: strengthening dike systems, clearing river flows for flood discharge, building reservoirs to reduce floods in upstream of big rivers, diverting and retaining floods, reforesting and protecting watersheds, intensify dike management and protection $[2,3]$. 
Before taking any of these measures, important information and data must be provided or predicted, and advanced modeling technologies are a privileged tool for such decision making.

The Institute of Mechanics has been involved in many research projects concerning the problem of integrated water resources management in the Red River Basin. Here it is mentioned some projects supported by European Commission, by the Ministry of Science \& Technology, Vietnamese Academy of Science \& Technology and Ministry of Agriculture \& Rural Development as indicated in the Introduction.

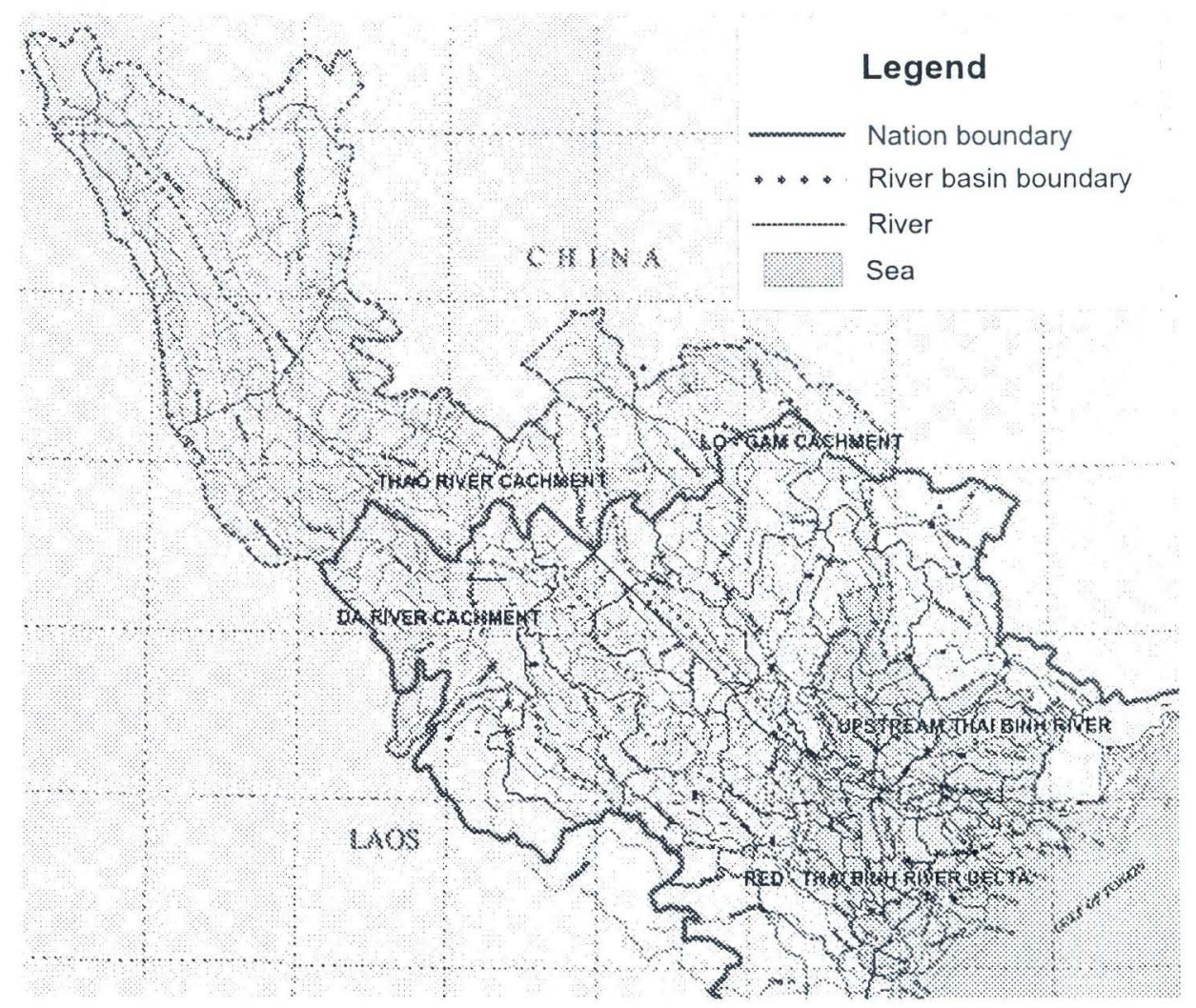

Fig. 1. Red River Basin (source: VIWRP, MARD)

In participating in these projects, the Institute of Mechanics has collected and created a data base, has developed and used different modeling tools - first elements of DSS for flood control \& management in the RRB [2 - 9]:

- Database

- Hydrological model

- One and quasi two dimensional hydraulic model

- Flood forecasting model using a hydrological \& one and quasi two dimensional models

- Two dimensional hydraulic model

- Flash flood forecasting model using a hydrological, one and two dimensional models

- One and two dimensional hydraulic dam \& dike break flow model 
- Socio-economic model for evaluating damages caused by flood

- Pilot Decision Support System coupling above indicated models [Fig. 2]

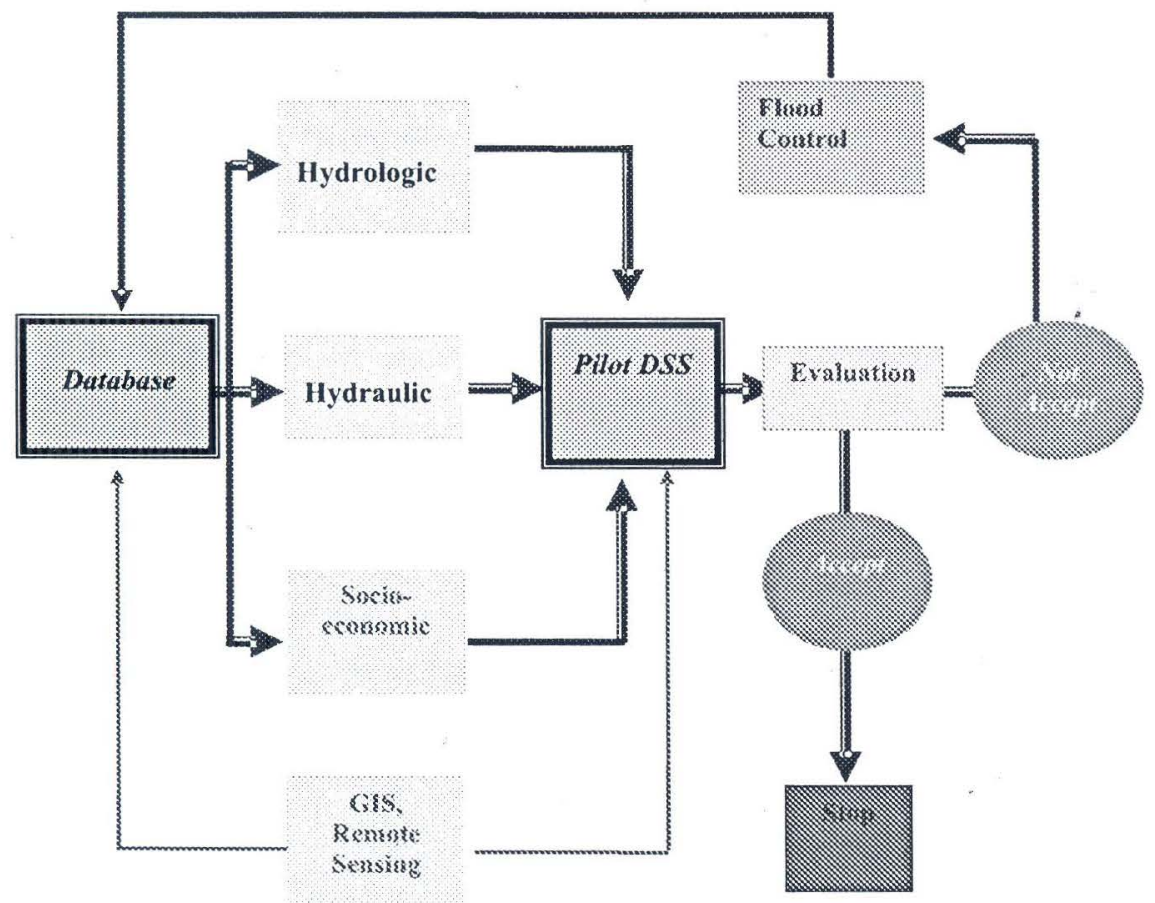

Fig. 2. Pilot Decision System for Flood Control in the Red River Basin

In the following parts it is selected only some investigations of the Institute of Mechanics in developing hydraulic models for flood forecasting and flood control in the Red River System [2-6].

\section{ONE- AND QUASI-TWO DIMENSIONAL HYDRAULIC MODEL FOR THE COMPLEX RIVER NETWORK - VALIDATION AND APPLICATION IN THE RED RIVER SYSTEM}

\subsection{Basic Equations}

The free surface flow in a single branch of a river network can be described by the so-called Saint-Venant equations $[2,3]$ under the assumption of a hydrostatic pressure and uniform distribution of the velocity along the vertical axis.

In practice, the flow in the main channel and flood plain are quite different due to different frictions. So the following type of equations is often used:

$$
\begin{gathered}
\frac{\partial A_{s}}{\partial t}+\frac{\partial Q}{\partial x}=0 \\
\frac{\partial Q}{\partial t}+\frac{\partial}{\partial x}\left(\frac{Q^{2}}{A_{f}}\right)+g A_{f} \frac{\partial Z}{\partial x}+g A_{f} \frac{Q|Q|}{K^{2}}=0
\end{gathered}
$$

where $Z$ - water elevation, $Q$ - discharge, $A_{s}$ and $A_{f}$ - wet cross sectional areas for the main and total flow, $K$ - conveyance, $t$ - time, $x$ - space coordinate. 
The continuity equation for storage cells is following

$$
\frac{d V}{d t}=\sum Q
$$

where $V$ is the water volume, $Q$ is in- and out-going discharges.

The flow must be conservative, so at confluences or tributaries the sum of all discharges must be zero. At hydraulic structures flow rate is defined by the empirical formula:

$$
Q=f\left(Z_{t l}, Z_{h l}, a\right)
$$

where $Z_{t l}, Z_{h l}$ are the upstream and downstream water levels and $a$ is characteristic parameter of structures. A structure may be modeled by one of two types: a spillway and a sluice.

Finally the initial and boundary conditions must be added.

\subsection{Method of solution}

To get numerical solutions the considered river network is split into river branches, separated by nodes $[2,3]$. A node is point in a river system where the Saint-Venant equations are not valid. A confluence or a tributary is a node. For a hydraulic structure in rivers it is associated with two nodes- upstream and downstream due to different water levels.

If the network consists of storage cells, that make the problem to be quasi-two dimensional, they are nodes also. Therefore structures that link rivers and storage cells have two nodes too.

The numerical method is based on the implicit 4-points Preissmann method for river branches, implicit finite difference scheme for storage cells and linking discharges of hydraulic structures.

\subsection{Validation of the model by test-cases developed in European hydraulic laboratories}

To verify 1-D hydraulic model, one can use the test cases developed by the European hydraulic laboratories. These 12 test cases are divided into 3 groups as follows: Test case No 1: Released wave in a rectangular channel, No 2: Steady sub-critical flow in a rectangular channel branch, No 3: Steady flow in a network with sub discharges, No 4: Steady flow through a structure, No 5: Dynamic wave, No 6: Diffusion wave, No 7: Kinematical wave, No 8: Wave through a reservoir, No 9: Local disturbance in steady flow, No 10: Steady flow for non-uniform geometry, No 11: Unsteady flow in complex riverbed, No 12: Tributaries.

The model has been verified by the 12 above mentioned test cases [2-3].

\subsection{One and quasi-two dimensional hydraulic model for Red River System}

For the application of the model to the Red-Thai Binh river network, it is necessary to develop 1 \& quasi-2D hydraulic model [2-3]. This model is constructed to adapt the existing flood protection rules:

- Simulating flood in river network,

- Simulating flood into Day river through the flood diversion structure of the Van Coc Sluice and the Day Dam when the water level at Hanoi is above $13.6 \mathrm{~m}$,

- Simulating flood into retention area if the flood diversion does not reduce the water level at Hanoi bellow $13.6 \mathrm{~m}$. 
The calculation network is shown in Figure 3. It is quasi-two dimensional and consists of a river network, flood diversion areas in the Day river catchments, retention areas Tam Thanh, Lap Thach, Luong Phu, Vinh Tuong.

Discharge boundaries of the network are given at stations: Hoa Binh on the Da river, Yen Bai on the Thao River, Thac Ba on the Chay river, Tuyen Quang on the Lo river, Lien Son on the Pho Day river, Phu Cuong on the Ca Lo river, Thac Huong on the Cau river, Cau Son on the Thuong river, Chu on the Luc Nam river, Chi Thuy on the Tich river and Hoang Long on the Hung Thi river. Water level boundaries are given on 9 estuaries: Day, Ninh Co, Ba Lat, Tra Ly, Thai Binh, Van Uc, Lach Tray, Cam, Da Bach.

The cross sections (topographical data) are measured in period 1999-2000 years.

For the Red - Thai Binh river network special treatments are needed to simulate flow through the Van Coc sluice and the Day dam because of their special operational rules and also to simulate flows from the river to the retention areas. In the case of big floods, the Red River Delta is split split into 278 storage cells using the DEM of $1 / 50,000$ scale (see Fig. 3).

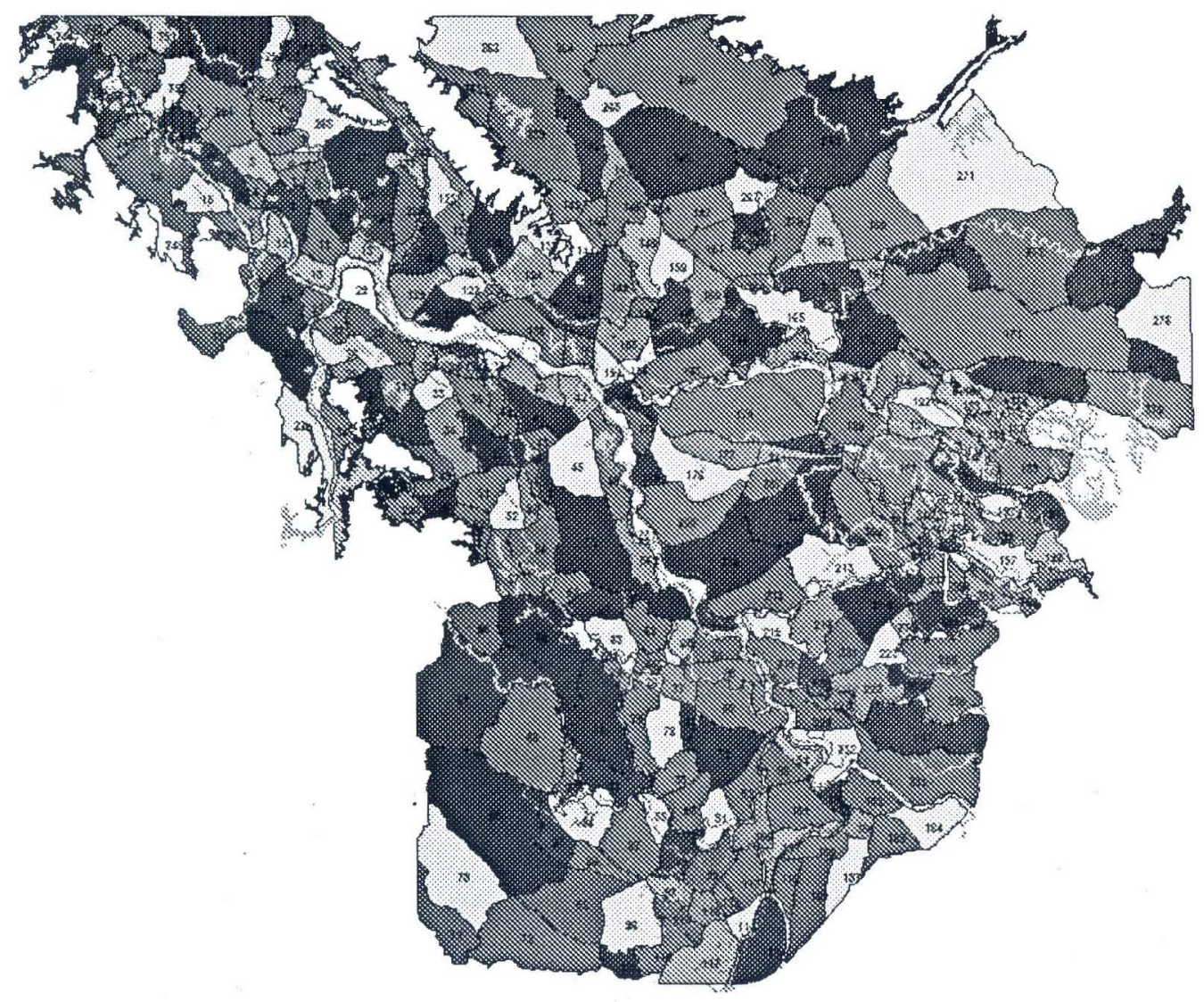

Fig. 3. The Red River Delta split by cells

Thecomputational schema of 1D hydraulic model for the Red River System is presented in Fig. 4 


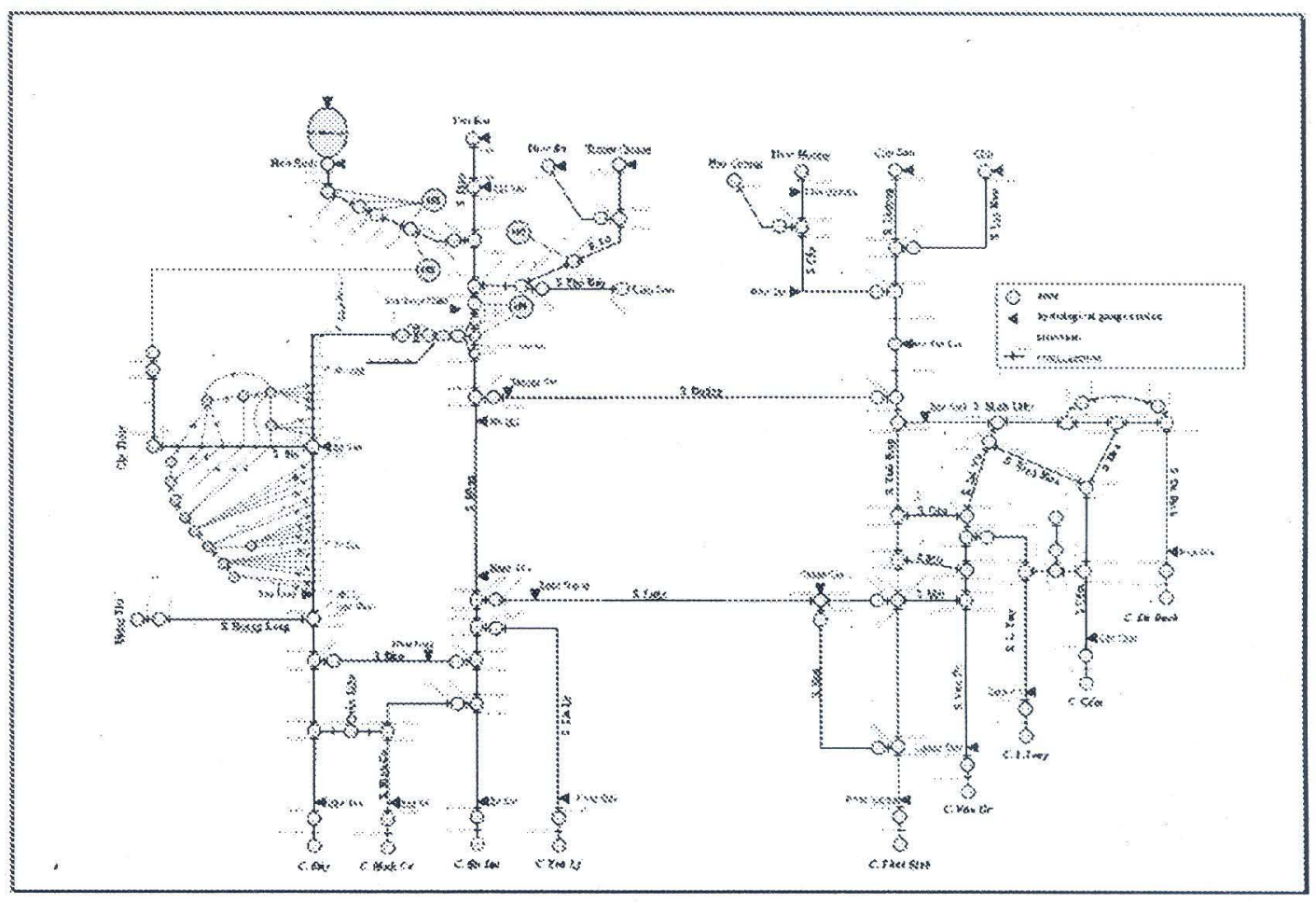

Fig. 4. Computational schema of 1D hydraulic model for the Red River System

\section{SOME NUMERICAL METHODS FOR SOLVING THE 1-D SAINT-VENANT EQUATIONS OF GENERAL FLOW REGIME - APPLICATION TO DAM BREAK FLOWS}

\subsection{Equations and numerical methods}

Let us consider the Saint-Venant equations of the form $[4,5]$

where

$$
\begin{aligned}
& \frac{\partial A}{\partial t}+\frac{\partial Q}{\partial x}=q \\
& \frac{\partial Q}{\partial t}+\frac{\partial}{\partial x}\left(\frac{Q^{2}}{A}+g I_{1}\right)=S_{d}
\end{aligned}
$$

$$
S_{d}=g A\left(S_{0}-S_{f}\right)+g I_{2}
$$

And $t$ is time, $x$ - space coordinate, $A$ - wet cross sectional area, $Q$ - discharge, $g$ gravity, $I_{1}, I_{2}$ - account for pressure forces, $S_{0}$ - bed slope, $S_{f}=\frac{|Q| Q}{K^{2}}$ - bed friction, $K$ - conveyance, $q$ - literal unit discharge.

By using the change rule of derivatives for $P(x, A)=g I_{1}(x, A)$ one gets another forms of source terms:

$$
\begin{gathered}
S_{d}=\left.\frac{\partial P}{\partial x}\right|_{A=\mathrm{const}}+\left.\frac{\partial P}{\partial A} \frac{\partial A}{\partial x}\right|_{z=\mathrm{const}}-g A S_{f}, \\
S_{d}=g A\left(S_{0}-S_{f}\right)+\left(\frac{\partial I_{1}}{\partial x}-A \frac{\partial h}{\partial x}\right)
\end{gathered}
$$




$$
S_{d}=-g A S_{f}+\left(\frac{\partial I_{1}}{\partial x}-A \frac{\partial z}{\partial x}\right),
$$

where $z$ is the water level.

In the vector form one can write:

$$
\frac{\partial U}{\partial t}+\frac{\partial F(x, U)}{\partial x}=S(x, U),
$$

where

$$
U=U(x, t)=\left(\begin{array}{c}
A \\
Q
\end{array}\right), \quad F(x, U)=\left(\begin{array}{c}
Q \\
\frac{Q^{2}}{A}+g I_{1}
\end{array}\right), \quad S(x, U)=\left(\begin{array}{c}
q \\
S_{d}
\end{array}\right) .
$$

Numerical methods for conservation laws are mainly developed for the homogenous equations, where the source terms are identical to zero. For the non-homogenous equations, like the Saint Venant equations, one uses numerical methods for conservation laws to solve the homogenous part, then uses the pointwise or upwind approaches to include the source terms.

The homogenous part of the equations is solved by numerical methods for conservation laws: the Lax-Friedrichs, the Self-adjusting Hybrid, the Nessyahu-Tedmor, and the Roe's approximation methods. The source terms can be discretized following the pointwise, upwind or mixed approaches. The mixed approach for discretization of source terms is recommended for balancing the flux and source terms.

\subsection{Verification of the numerical methods by Test-Cases}

There has been done a verification of 4 numerical methods for solving the SaintVenant equations: the Lax-Friedrichs, the Self-adjusting Hybrid, the Nessyahu-Tedmor, and the Roe's approximation methods. The source terms has be discretized following the pointwise, up-wind or mixed approaches. By the numerical tests it is recommended that upwind and the mixed approaches are more appropriated to the Saint-Venant equations, the Roe's approximation is an efficient method and can be used with all the source term approaches of discretization.

The Roe's approximation with the up-wind and mixed technique for the source terms has been tested in detail by following test-cases, covering all of three flow regimes: sub-, trans-, and super-critical: the water at rest problem, steady flow through a bump, the dry bed dam break problem, the wet bed dam break problem, the dry bed dam break problem. with friction, the dam break problem with a local constriction, and the hydrodynamic wave, the diffusion wave, the dynamic wave problems.

The Roe's approximation with up-winding and mixed technique for the source terms finally has been chosen for dam break modeling.

\section{SOME NUMERICAL METHODS FOR SOLVING THE 2-D SAINT-VENANT EQUATIONS AND THE 1 AND 2D LINKED MODEL FOR THE RED RIVER SYSTEM}

\subsection{The 2-D Saint -Venant Equations}

The water flow in a $2 \mathrm{D}$ domain can be described by the so-called the shallow water equations (the 2D Saint-Venant equations) [2-3]. In a conservative form they are written 
as follows:

$$
\frac{\partial U}{\partial t}+\frac{\partial E}{\partial x}+\frac{\partial G}{\partial y}=H
$$

with $H=H^{(1)}+H^{(2)}$,

$U=\left(\begin{array}{c}h \\ q_{x} \\ q_{y}\end{array}\right), E=\left(\begin{array}{c}q_{x} \\ \frac{q_{x}^{2}}{h}+\frac{g h^{2}}{2} \\ \frac{q_{x} q_{y}}{h}\end{array}\right), G=\left(\begin{array}{c}q_{y} \\ \frac{q_{x} q_{y}}{h} \\ \frac{q_{y}^{2}}{h}+\frac{g h^{2}}{2}\end{array}\right), H^{(1)}=\left(\begin{array}{c}0 \\ S_{0, x} \\ g h S_{0, y}\end{array}\right), H^{(2)}=\left(\begin{array}{c}0 \\ F\left(q_{x}\right) \\ F\left(q_{y}\right)\end{array}\right)$

where $h, q_{x}, q_{y}$, are unknown functions, $h=h(x, y, t)$ is the flow depth, $q_{x}=q_{x}(x, y, t)$ and $q_{y}=q_{y}(x, y, t)$ are the unit-width discharge components $\left(q_{x}=u h\right.$ and $q_{y}=v h$ with $u, v$ are the depth-averaged velocities) in $x$ and $y$ directions, respectively, $g$ is the gravity acceleration, $S_{0, x}, S_{0, y}$ are the bed slopes, $F\left(q_{x}\right), F\left(q_{y}\right)$ are the bed shear stresses in $x$ and $y$ directions, respectively:

$$
F\left(q_{x}\right)=-g q_{x} \frac{\sqrt{u^{2}+v^{2}}}{C_{h, x}^{2}}, \quad F\left(q_{y}\right)=-g q_{y} \frac{\sqrt{u^{2}+v^{2}}}{C_{h, y}^{2}} .
$$

$C_{h, x}=K_{s, x} h^{2 / 3}, C_{h, y}=K_{s, y} h^{2 / 3}$, where $C_{h, x}, C_{h, y}$ and $K_{s, x}, K_{s, y}$ are Chezy and Strickler coefficients.

For the system of equations (4.6) the initial and boundary conditions must be added. The numerical method for this system is the finite volume one.

\subsection{The numerical methods and their validations by the test-cases}

Method of finite volume has been used for solving the equation system (5.1)- (5.3) together with the initial and boundary conditions.

First of all the Green's theorem technique and the Chorin's projection method have been applied to solve the Saint-Venant equations following the successive steps: convectiondiffusion, wave propagation and velocity correction.

For modelling 2D dam break flows the Roe's approximation method has been used.

The developed models have been validated by several academic tests: Total dam-break problem, Partial dam-break problem, Dam-break in a channel with a local constriction, Dam-break in a channel with a non symmetrical flood plain.

\subsection{Coupling between the 1-D and 2-D Hydraulic Models}

In many cases, the coupling between the 1D and 2D Hydraulic Models is necessary for flood control in the Red River Delta. The following schema for the coupling 1D \& 2D is developed and used:

- With the known water level at time step $n$ from 2D Model, at the time step $n+1$, use the 1D Model for calculating the discharge in the connecting section.

- Using the discharge at time step $n+1$ from 1D Model, calculate the water level in the connecting section at time step $n+2$ by the 2D Model.

- The iteration process will be finished when the difference between the water levels from two models is small enough. 


\section{SOME APPLICATIONS OF HYDRAULIC MODELS FOR FLOOD FORECASTING AND FLOOD CONTROL IN THE RED RIVER SYSTEM}

Many obtained scientific results have been transferred to and used in some organizations, for example, the Central Committee for Flood and Storm Prevention, National Centre for Meteor-Hydrological Forecasting and other water resources management and planning organizations [2-3]. Here it will be presented two examples.

\subsection{Flood Forecasting in the Red River System}

By request of the Central Committee for Flood and Storm Prevention, from the 2002year flood season, Institute of Mechanics, every day (from June, 16 unt il September, 15), forecasts the discharge into Hoa Binh reservoir and the water level in Hanoi for 48 hours by using the Hydrological Model, 1D Hydraulic Model and Reservoir Operation Model.

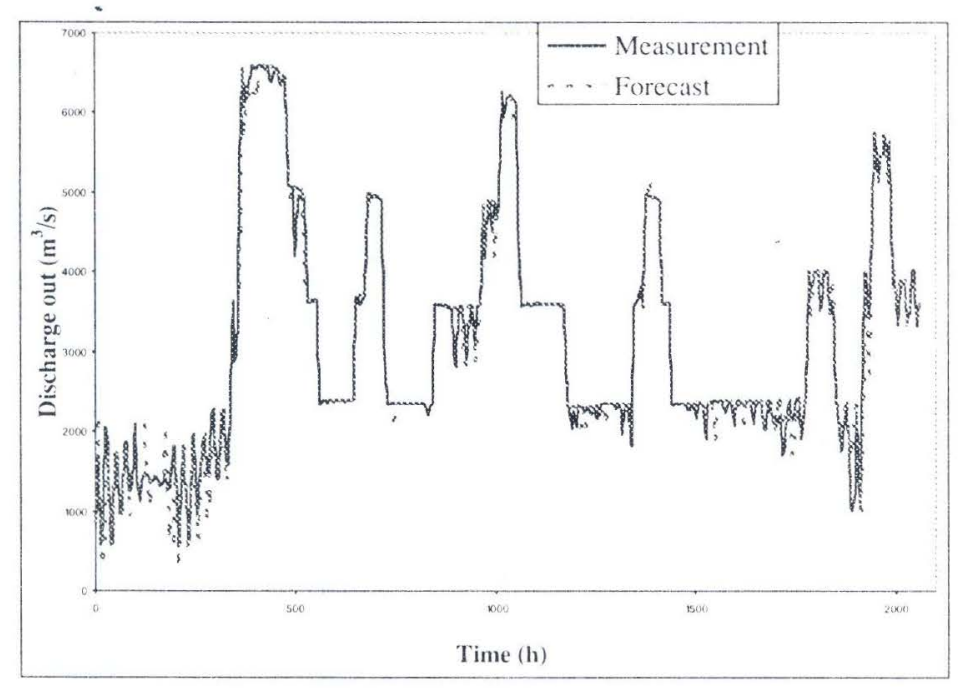

Fig. 5. Predicted \& measured discharge from Hoa Binh reservoir

According to Vietnamese regulations, these values are the main and most important parameters for taking any flood control measure. Some forecasting results are presented in Fig. 5-6.

By evaluation of the Central Committee these forecasting results are acceptable. 


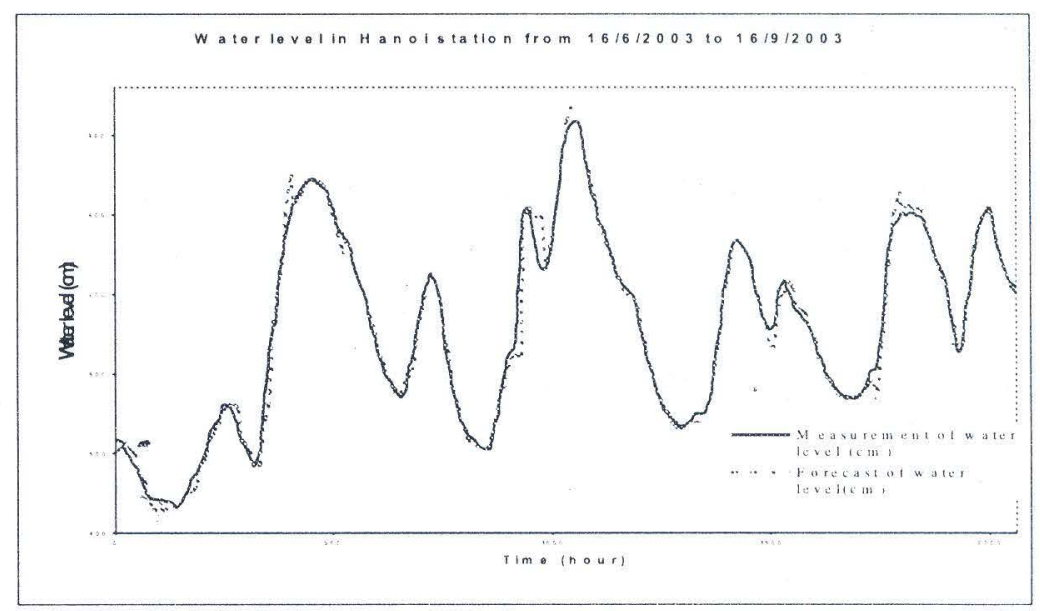

Fig. 6. Predicted \& measured water level at Hanoi

\subsection{Evaluating of Flood Control Measures in the Red River System}

Table 1. The effectiveness of flood reduction for 500-year flood of 1996-year shape

\begin{tabular}{lllll}
\hline Scenario & $\begin{array}{l}\text { No protection } \\
\text { measures }\end{array}$ & $\begin{array}{c}\text { Hoa Binh } \\
\text { operation }\end{array}$ & $\begin{array}{c}\text { Hoa Binh } \\
\text { +Day dam } \\
\text { operation }\end{array}$ & $\begin{array}{l}\text { All Flood } \\
\text { protection } \\
\text { measures }\end{array}$ \\
\hline$Z_{\max }$ Ha Noi $(\mathrm{m})$ & 15.53 & 14.58 & 13.97 & 13.92 \\
$Q_{\max }$ Ha Noi $\left(\mathrm{m}^{3} / \mathrm{s}\right)$ & 40.475 & 31.361 & 26.071 & 25.665 \\
$Z_{\max }$ Son Tay $(\mathrm{m})$ & 18.62 & 17.34 & 16.69 & 16.61 \\
$Q_{\max }$ Son Tay $\left(\mathrm{m}^{3} / \mathrm{s}\right)$ & 49.470 & 38.632 & 36.952 & 35.849 \\
\hline$Z_{\max }$ Va Coc $(\mathrm{m})$ & & & 15.43 & 15.43 \\
\hline$Q_{\max }$ Day Dam $\left(\mathrm{m}^{3} / \mathrm{s}\right)$ & & $4.19 \mathrm{E} 3$ & $4.02 \mathrm{E} 3$ \\
\hline$Z_{\max }$ Tam Thanh $(\mathrm{m})$ & & 21.90 & 21.42 \\
\hline$Z_{\max }$ Lap Thach $(\mathrm{m})$ & & 13.26 & 18.08 \\
\hline$Z_{\max }$ Luong Phu $(\mathrm{m})$ & & 16.16 & 18.80 \\
\hline V Day Dam & 115.60 & & $1.1 \mathrm{E} 9$ \\
\hline$Z_{\max }$ Hoa Binh reservoir $(\mathrm{m})$ & & & \\
\hline
\end{tabular}

The 1-D \& quasi 2-D IMECH model is used for evaluating the effectiveness of flood reduction by taking flood protection measures (when threre are only Hoa Binh and Thac Ba reservoirs) for the floods with return period of 500-year and 1000-year

To solve this problem it is necessary to:

- Evaluate Upstream Discharges for the Red River System for extreme floods with return period of 500 and 1000 years.

- Evaluate prepared flood control measures (reservoir operation, diversion and detention zones) to protect these extreme floods.

- Evaluate the role of new measure - emergency spillways to protect these extreme floods. 
In the Table 1 it is presented the result of evaluating the effectiveness of flood reduction for 500-year flood of 1996-year shape when no emergency spillways are used.

\section{CONCLUSION AND ACKNOWLEDGMENTS}

As indicated in the Introduction, I started my research \& development activity in the field of environmental and natural fluid mechanics from the 1979 year, when, by the proposal of Prof. Nguyen Van Dao, I had a one year's stay at the Laboratoire National d'Hydraulique de France, Chatou, France. Until now, this activity is still my most important one. Together with my colleagues from the Institute of Mechanics, we have received some research \& development results in the problems of environmental and natural fluid mechanics, especially in the problems of hydromechanics for flood forecasting and flood control in the Red River System.

To express my personal gratitude, I select some recent scientific results, obtained by my group in the Institute of Mechanics, to publish in the special issue of the Vietnam Journal of Mechanics, dedicated to the memory of Prof. Nguyen Van Dao, with whom I had a big chance to contact, to work and to collaborate during about 30 years.

In this occasion my acknowledgments are also expressed to the VAST, MOST, MARD and European Commission for financial support to realize many scientific projects in the field of water resources research.

\section{REFERENCES}

1. Nguyen Van Diep, Some Features in the Development of Modern Mechanics, Collection of Research Works, Laboratory of Mechanics, Vietnam Institute of Sciences, pp. 7-15, 1978 (in Vietnamese).

2. Nguyen Van Diep, National project KC08-13 "Studying the Scientific Basis for Flood Forecasting and Flood Control in the Red River Basin", Final Report, 2005 (in Vietnamese).

3. Nguyen Van Diep, International project "Decision Support System for Ecosystem Upgrading and Flood Control of a Sustainable Development in the Red River System-Pilot Phase" FLOCODS, European Commission, 2002-2004, IMECH Technical Report, 2004.

4. Nguyen Van Hanh, Nguyen Van Diep, Ngo Huy Can, On Some Numerical Methods for Solving the 1-D Saint-Venant Equations of General Flow Regime. Part 1: Numerical methods, Vietnam Journal of Mechanics 24 (4) (2002).

5. Nguyen Van Hanh, Nguyen Van Diep, Ngo Huy Can, On Some Numerical Methods for Solving the 1-D Saint-Venant Equations of General Flow Regime. Part 2: Verification and Application, Vietnam Journal of Mechanics 25 (1) 2003.

6. Dan Nguyen, Dartus D., Diep Nguyen Van, New Development of Overland and Hydraulic Models for Flood Controls in the Red River Delta, J. of Advances in Natural Sciences 5 (2) (2004).

7. Nguyen Van Diep, Ngo Huy Can, Hoang Van Lai, Nguyen Hong Khanh, First Elements of the Decision Support System for Flood Control in the Red - Thai Binh River System, Proceedings of the International Workshop on Flood Prevention and Control in the Yangtze River (FOCYR), Wuhan, China, 2004.

8. Nguyen Van Diep, Ngo Huy Can, Nguyen Kim Dan, Development and Application of Decision Support System for Flood Control in the Red River Delta, International Conference on Reservoir Operation \& River Management (ICROM), Guangzhou and Three Gorges, China, 2005. 
9. Nguyen Van Diep, Ngo Huy Can, Numerical Modelling Tools for Flood Forecasting and Flood Control in the Red River Basin, The th $^{\text {th }}$ Int. Conf. on Hydroscience and Engineering (ICHE2006), Sep. 10 - Sep. 13, Philadelphia, USA, 2006.

Received July 29, 200\%.

\section{MộT SỐ VẤN ĐỀ THUỶ DộNG LỰC TRONG VIỆC DỰ BÁO VÀ KIỂM SOÁT LŨ LỤT Hệ THỐNG SÔNG HỒNG}

Hoạt động nghiên cứu và phát triển của tôi trong lĩnh vực Cơ học Chất lỏng tự nhiên và môi trường được bắt đầu từ sau chuyến công tác 1 năm tại viện Thưy lực Quốc gia, Pháp (1979-1980) theo đề nghị của Giáo sư Nguyễn Văn Đạo. Cho đến nay, hoạt động này vẫn là hoạt động quan trọng nhất của tôi.

Trong bài báo trình bày một số kết quả khoa học lựa chọn của một trong những vấn đề Thủy động lực học phục vụ việc dự báo và kiểm soát lũ lụt: phát triển mô hình thủy lực 1 chiều, mô hình thủy lực 1 và giả 2 chiều, mô hình thủy lực một chiều cho dòng cháy do vỡ đập, mô hình thưy lực 2 chiều, kết nối mô hình thưy lực 1 và 2 chiều và một số ứng dụng của chúng trong dự báo và kiềm soát lũ lụt hệ thống sông Hồng.

Bài báo nhằm tường niệm Giáo sư Nguyễn Văn Đạo, người mà tôi có dịp được làm việc và cộng tác gần 30 năm qua, và tôi muốn bày tó lòng cảm ớn chân thành của mình tới Giáo sư. 